who suffered death by burning at the hands of Calvin. Although it is a theological work, it contains an account of the pulmonary circulation. Only two other copies of the book are known to exist. There are also on view first editions of "De Re Medicina" by Celsus, dated 1478; Vesalius' "Fabrica", 1543 ; Harvey's "De Motu Cordis", 1623 (from the library of Alexander Monro tertius); Willis's "Cerebri Anatome", with illustrations by Sir Christopher Wren; Jenner's "Inquiry into the Causes, etc., of Cowpox", 1798 ; and of W. T. G. Morton's brochure on the use of ether as an anæsthetic, 1847. One of the show-cases contains a collection of illustrated herbals, and a catalogue, dated 1683, of the Physic Garden, Edinburgh, which occupied part of the present site of Waverley Station. The exhibition is remaining open, during library hours, until the end of June.

\section{Geographical Research Memoirs}

AT a recent meeting, the Council of the Royal Geographical Society decided to inaugurate a new Geographical Research Series of Special Publications. The Council's object is to facilitate the publication of scientific memoirs on any aspect of geography, too long or too specialized for publication in the Geographical Journal. The cost of publication will be met by the Society. Each memoir, in style and format similar to the Geographical Journal, will not normally exceed sixty-four pages of print, and allowance has been made in estimating cost for a limited number of plates, maps, and figures in the text. The distribution will be about five hundred copies. While papers offered for publication are normally expected to be the products of mature scholarship, theses for a doctorate or similar research degree from postgraduate students will also be considered. Papers for this series should be sent to the Secretary, who will submit them for consideration by the Publications Committee of the Society.

\section{Manchester Museum}

IN spite of staffing and storage difficulties, it is stated in the report for the year 1944-45 of the Manchester Museum that departmental routine work has been progressive. Several collections stored away from the Museum during the War have now been returned and are again on exhibition. An experiment which will be of interest to other museums developing school services was the loan of a quantity of Australian material to a school which had been studying that country. The specimens (minerals, plants, insects, mammals, etc.) were arranged by the pupils themselves as an end-of-term exhibition to illustrate the class-work covered. Another interesting scheme was organised by the Extra-Mural Department of the University of Manchester. This took the form of "One-day Schools" for men and women of the Royal Army Ordnance Corps, who spent whole days in the Museum, where they were introduced to a number of scientific hobbies and told how the Museum could help them if they became interested in any one of them. Talks and discussions with members of the Museum staff took place in the class-rooms, and these were followed by inspection of the various collections in the galleries appropriate to the hobbies. The success of the scheme suggests that further work along these lines might be usefully developed. A short list of publications, a list of museum lectures given during the year, and a list of acquisitions are appended to the report.

\section{Linnean Society of London}

AT the anniversary meeting of the Linnean Society of London held on May 24, Prof. G. R. de Beer was elected president for the period 1946-47. The following elections also took place : New Members of Council, Prof. G. R. de Beer, Dr. R. Dennell, Dr. A. T. Hopwood, Mr. H. W. Parker and Dr. W. B. Turrill; Treasurer, Colonel F. C. Stern; Secretaries, Dr. Malcolm Smith (zoology), Dr. B. Barnes (botany). Forty new fellows were elected.

The following foreign members were also elected : Prof. Jan Bělehrádek, rector of the University of Prague; Prof. H. Boschma, director, Natural History Museum, Leyden; Dr. Josias BraunBlanquet; Prof. Edouard Chatton; Dr. François Gagnepain ; Prof. Johan Hjort, president, Inter. national Council for the Exploration of the Sea ; Dr. N. A. Maximov, director, Institute of Plant Physiology, Moscow; Knud Hensch Stephensen, Zoological Museum, University, Copenhagen ; Dr. Victor van Straelen, director, Natural History Museum, Brussels ; Prof. Johanna Westerdijk, Centraalbureau voor Schimmelcultures, Baarn, Netherlands.

Mr. Frederick J. Pittock was elected an associate honoris causa.

In his presidential address, after making some remarks on the welfare of the Society, Mr. A. D. Cotton, the retiring president, made some further observations on his studies of "Tree Senecios of Africa".

\section{Royal Microscopical Society}

THE following have been elected officers of the Royal Microscopical Society for 1946-47: President, Dr. James A. Murray; Vice-Presidents, Mr. J. E. Barnard, Dr. G. M. Findlay, Mr. C. F. Hill, Dr. T. E. Wallis; Hon. Treasurer, Mr. S. R. Wycherley ; Hon. Secretaries, Dr. R. J. Ludford, Dr. H. Moore ; Ordinary Members of Council, Mr. F. D. Armitage, Dr. L. P. Clarke, Dr. F. Greenshields, Mr. F. C. Grigg, Mr. N. Ingram Hendey, Major Maxwell Knight, Dr. J. E. McCartney, Mr. Chetwynd Palmer, Mr. R. Ross, Mr. D. J. Scourfield, Mr. E. Wilfred Taylor, Mr. J. M. Watson; Hon. Editor, Dr. G. M. Findlay; Hon. Curator of Instruments, Mr. Chetwynd Palmer ; Hon. Curator of Slides, Mr. N. Ingram Hendey; Assistant Secretary and Librarian, Mr. J. W. Kettlewell.

\section{Royal Society of South Africa}

THw following have been elected officers of the Royal Society of South Africa for 1946: President, Prof. R. S. Adamson; Secretary, Mr. A. J. H. Goodwin ; Treasurer, Prof. R. W. James; Librarian, Prof. E. Newbery ; Editor of Transactions, Dr. A. L. du Toit ; Members of Council, Prof. D. Burnett, Prof. P. J. du Toit, Prof. B. L. Goodlet, Prof. A. P. Goossens, Dr. J. Jackson, Mr. J. G. Rose, Prof. I. Schapera, Prof. B. F. J. Schonland, Prof. F. Walker and Dr. C. L. Wicht.

\section{Announcements}

Dr. R. H. BARFIELD, a principal scientific officer of the Radio Division, National Physical Laboratory, has been appointed to the research and development staff of Wild-Barfield Electric Furnaces, Ltd.

A series of four lectures on "Problems of Modern Biology in Relation to Atomic Physics" will be delivered by Dr. Max Delbrück, of Vanderbilt Univer. sity, Tennessee, in the University of Manchester on June $11,12,13$ and 14. 